began, especially from A.D. 400 (when the sea route from South China also became important), to depend on India for their cultural intercourse. China had partly ${ }^{4}$ depended on the West for glass as the West depended on China for silk. The art of glass-making was reintroduced to the Chinese by the IndoScythians in the 5th century and in the 6th century the silkworm was concealed in a bamboo cane and introduced to the West, probably by Indian monks.

The inflow of Indian ideas to China at this time was terrific. Religion and Art were perhaps more important than Science, but from c. 440 there occurred a second period of Chinese Science stimulated by fresh ideas received from India. A graph of the accuracy of $\Pi$ in China shows that in this period and especially in the early part it was better known than at any other time before the arrival of modern European mathematics. After A.D. 650 Science declined generally, not only in India itself but also in the Far East and the West.

About A.D. 750 the Chinese invention of paper was received in Mesopotamia and helped to stimulate the scientific renascence which began at Baghdad shortly afterwards, and in the great period of which $c$. 820s John Mesue flourished. Meanwhile Chinese ideas on Alchemy had been returning via the Silk Road and cross-fertilizing with the chemistry of the Fertile Crescent to produce under the Arabs medieval alchemy proper.

In the 13th century cultural interchange began on a vast scale in the days of the Pax Tartarica and some of the results at Pekin and Maragha have been discussed recently by Dr. Martin Johnson in his Art and Scientific Thought. The fruits were, however, very short-lived.

In the 16th century ideas began to pass by the sea route, but in the 18th century Chinese influence on the Arts of Europe was very considerable. Leibniz had suggested that Chinese missionaries should be sent to Europe and Wolff was expelled from Halle for an address in praise of Confucius, but by that time most of the scientific heritage of China had already reached Europe.

4 Professor Goodrich has pointed out that a Chinese-made glass (containing barium) is widely distributed in the fifth-third centuries B.C. in North China. See Bull. Mus. Far Eastern Antiq. No. 10, 1938, 1-64. Iron appears to have been developed in the Wu (Soochow) area of N. E. China probably about the sixth-fifth centuries B.C.

\title{
Bartolomeo Telioux and the Early History of the Thermometer
}

\author{
By J. A. CHALDECOTT, M.Sc., A.Inst.P. \\ (Assistant Keeper, Science Museum) \\ ABSTRACT of Paper read on 26th May, 1952
}

An illustration of Santorio's thermometer which appears in Biancani's Sphaera Mundi (Bologna, 1620) was previously thought to be the first illustration of a thermometer of the single-bulbed pattern. However, a recent examination of a manuscript written by Bartolomeo Telioux and now preserved in the Library of the Arsenal, Paris (MS. No. 8525), has revealed that another illustration of an instrument of this type existed as early as 1611. Additional interest attaches to this illustration by virtue of the fact that a thermometer scale is also depicted behind the instrument, whereas the first instrument of Santorio (1611) was without a scale. Telioux's scale is of eight degrees and each degree is further divided into sixty minutes, with graduations at tenminute intervals, a system of scaling possibly suggested by analogy with the graduation of astronomical instruments. 
The Italian text which accompanies the drawing shows that Telioux did not understand the principle of operation of the instrument; furthermore, certain features of the outline of the apparatus, as depicted in the drawing, make it unlikely that Telioux ever attempted to construct such an instrument himself. Bearing these points in mind, one is perhaps justified in believing that the idea of a thermometer with an attached scale was known to several people in Italy as early as 1611. Unfortunately, we are not in a position to say whether this knowledge would derive from the instrument attributed to Galileo in or after 1592.

An incorrect assertion that the Telioux thermometer was independent of atmospheric pressure variations was made by G. Libri in his Histoire des Sciences mathématiques en Italie, depuis la renaissance des lettres jusqu'à la fin du dix-septième siècle (Paris, 1841, 4, 471). No such claim was advanced by Telioux, and it is clear from an examination of the drawing that any readings made with the instrument would be affected by changes in barometric pressure since the system was not sealed in any way.

The availability of the manuscript before it passed into the possession of the Library of the Arsenal, in Paris, in 1757, is not known, and it is therefore not possible to form any judgment of the influence, if any, which the information contained in the manuscript may have had on contemporary thought. 